\title{
Silicon availability and cell-cycle progression in marine diatoms
}

\author{
Mark A. Brzezinski ${ }^{1,2, *}$, Robert J. Olson ${ }^{1}$, Sallie W. Chisholm ${ }^{2}$ \\ ${ }^{1}$ Biology Department, Woods Hole Oceanographic Institution, Woods Hole, Massachusetts 02543, USA \\ ${ }^{2}$ Ralph M. Parsons Laboratory, Massachusetts Institute of Technology 48-425, Cambridge, Massachusetts 02139, USA
}

\begin{abstract}
The role of silicon availability on cell-cycle progression in marine diatoms was examined using flow cytometric methods. Silicon deprivation halted the progression of cells through the cell cycle with cells arresting in G1, G2 and $M$ in 6 of 7 species examined ( 5 centric and 1 pennate species). The exception, Phaeodactylum tricornutum, did not require silicon for growth and did not have a silicondependent segment within its cell cycle. This species was also the only one lacking a light-dependent arrest point late in its cell cycle suggesting that the arrest of diatom cells in G2 and $\mathrm{M}$ in the dark is related to silicon metabolism. Chaetoceros spp. were unique in that they had 2 silicon-dependent segments in G1: one at the G1/S boundary apparently associated with a silicon requirement for DNA. synthesis and a second earlier in G1 associated with the deposition of siliceous setae. Silicon limitation of Thalassiosira weissflogii led to an increase in the duration of G2 with the duration of G1, S and $M$ remaining as observed under nutrient-replete conditions. In severely limited cells, G2 comprised $82 \%$ of the cell cycle and lasted for over 2 d. More complicated responses were observed for Cylindrotheca fusiformis and Chaetoceros simplex. Modest silicon limitation of $C$. fusiformis led to increases in the duration of G2 and possibly M. More severe silicon stress did not lengthen M further, but both $G 2$ and G1 increased in duration. For C. simplex, modest silicon limitation led to the expansion of G1 alone, while more severe limitation lengthened G1, G2 and M. Changes in cell cycle durations in this species appeared related to a decline in the silicon content of siliceous setae deposited during G1 These results corroborate past observations that silicon metabolism is linked to specific segments of the cell cycle, but indicate that these regions can lengthen dramatically in response to silicon limitation.
\end{abstract}

\section{INTRODUCTION}

Diatoms are abundant, often dominant, members of the phytoplankton. Since they have an obligate silicon requirement for growth (Lewin 1962), the availability of silicic acid can strongly affect their population dynamics. Silicic acid concentrations in the surface ocean are often depleted to levels known to limit the growth of diatoms in culture (Guillard et al. 1973, Paasche 1973, Harrison 1974, Thomas \& Dodson 1975). Direct demonstrations of substrate limitation of silica production in natural diatom assemblages have been made in a variety of ocean habitats (Goering et al. 1973. Azam \& Chisholm 1976, Nelson et. al. 1981, Brzezinski $\&$ Nelson 1989) verifying the close ties between silicon metabolism and the ecology of diatoms.

Silicon uptake and deposition appear to be largely confined to the period between cytokinesis and daugh-

- Present address: Department of Biological Sciences, University of California, Santa Barbara, California 93106, USA.

(C) Inter-Research/Printed in F. R. Germany ter cell separation and are associated with the formation of new siliceous valves just prior to cell division (Lewin et al. 1966, Eppley et al. 1967, Darley et al. 1976, Sullivan 1977, Crawford \& Schmid 1986). In some species, such as Chaetoceros gracilis, a large fraction of cellular silicon is located in siliceous setae which are deposited just after daughter cell separation (Rogerson et al, 1986), but the timing of silicon uptake for setae formation is unknown. Silicon is required in lesser amounts for other important aspects of cellular metabolism including DNA replication (e.g. Darley \& Volcani 1969, Okita \& Volcani 1980).

The association of silicon metabolism with such key events as cell division and DNA replication creates a close coupling between silicon metabolism and the cell cycle. Diatom cell cycles follow the typical pattern of eukaryotic cells where mitosis (M) and cell division are separated from the period of DNA replication (S) by 2 gap phases denoted G1 and G2 (Mitchison 1971). When growth ceases as a result of silicon deprivation, cells arrest at specific points within the cell cycle. 
Silicon starvation of the pennate diatoms Navicula pelliculosa, Navicula saprophila, Nitzschia angularis and Cylindrotheca fusiformis leads to the accumulation of cells near the point of frustule formation in G2 or M1 and just prior to DNA synthesis near the G1/S boundary (Darley 1969, Sullivan 1976, Okita \& Volcani 1978, 1980, Blank \& Sullivan 1979, Blank et al. 1986) with the percentage of cells arresting at each point being dependent on the culture conditions for some species (Darley 1969, Okita \& Volcani 1978, 1980).

Centric diatoms have not been examined to the same extent as the pennates. This is mainly because most studies of silicon metabolism and the cell cycle have relied on synchronized cultures, and centric diatoms are not amenable to synchronization (Chisholm et al. 1980). Flow cytometry provides an alternative to synchronous cultures in that the position of individual cells within the cell cycle is determined by their relative DNA content. Vaulot et al. (1987) used flow cytometric methods to examine silicon-starvation arrest in the centric diatom Thalassiosira weissflogii and discovered that silicon deprivation blocks cells both near the G1/S boundary and late in $G 2$ or $M$ as observed for the pennates.

Flow cytometry can also be used to determine cellcycle stage durations in asynchronously growing populations (Slater et al. 1977). This technique has been used to examine changes in the duration of cell-cycle stages of marine phytoplankton growing in chemostats under nitrogen limitation (Olson et al. 1986a, b). Nitrogen limitation of the coccolithophore Hymenomonas carterae, the dinoflagellate Amphidinium carteri and the diatom Thalassiosira weissflogit leads to the expansion of G1 exclusively (Olson et al. 1986a, b) consistent with the arrest of nitrogen-starved cells in G1. (Vaulot et al. 1987). In contrast, silicon-starved cells arrest in both G1 and G2 and/or M (e.g. Darley \& Volcani 1969, Vaulot et al. 1987) suggesting that more than one stage of the cell cycle would increase in duration under silicon limitation. We examined this possibility using the marine diatoms $T$. weissflogii, Cylindrotheca fusiformis and Chaetoceros simplex. We also examined the response of the cell cycle to silicon starvation in 2 pennate and 5 centric species representing a broad range in frustule morphology and degree of silicification. The results indicate that the number and position of silicon-dependent arrest points varies depending on interspecific differences in the timing of siliceous hard part formation during the cell cycle

\section{METHODS}

A culture of Minutocellus polymorphus was obtained from the collection of Robert Olson at the Woods Hole
Oceanographic Institution (Massachusetts, USA). Cultures of all other species (Table 1) were obtained from the National Culture Collection of Marine Phytoplankton at the Bigelow Marine Laboratory for Ocean Sciences (Maine, USA). All cultures were unialgal, but not axenic. They were maintained in $\mathrm{f} / 2$ enriched seawater medium with added silicon (Guillard 1975) at $19^{\circ} \mathrm{C}$ under continuous illumination. All experiments were conducted at $19^{\circ} \mathrm{C}$ in $\mathrm{f} / 2+\mathrm{Si}$ enriched Sargasso Sea water. Illumination was provided continuously by Cool White fluorescent lamps covered with neutral density screens to provide a photon fluence rate of 100 $\mu \mathrm{E} \mathrm{m}^{-2} \mathrm{~s}^{-1}$ inside the culture vessels. None of the species were observed to form chains during the experiments.

Exponential growth. Batch cultures of each species were maintained in exponential growth in $30 \mathrm{ml}$ polycarbonate culture tubes under the experimental culture conditions for 2 wk prior to each experiment. Then replicate $500 \mathrm{ml}$ polycarbonate flasks containing 300 to $400 \mathrm{ml}$ of medium were inoculated to cell densities between $10^{3}$ and $10^{4}$ cells $\mathrm{ml}^{-1}$. Cell abundances were monitored daily. The cultures were sampled during exponential growth when cell abundances were $<20 \%$ of their maximum yield. Samples were taken for cellular silicon, carbon and nitrogen content and cell-cycle stage analysis and analyzed as described below. In addition, a minimum of 20 cells of each species were measured under phase contrast microscopy using an ocular micrometer and the average cell surface area calculated using geometric approximations of cell shapes (e.g. Brzezinski 1985).

Silicon starvation. Replicate batch cultures were grown under the same conditions as described above except that the silicic acid concentration in the medium was adjusted to ensure silicon starvation during stationary phase. The appropriate $\mathrm{Si}: \mathrm{N}: \mathrm{P}$ elemental ratios were determined by growing each species, except Phaeodactylum tricornutum, in polycarbonate flasks containing $\mathrm{f} / 2$ medium with varying concentrations of silicic acid and determining the concentration range over which cell yield was linearly related to the initial silicic acid concentration. The $\mathrm{Si}: \mathrm{N}$ ratios (by atoms) used were 1.10 for Thalassiosira weissflogii, 1.18 for Thalassiosira pseudonana, $1: 25$ for Chaetoceros muellerii and Chaetoceros simplex and 1.200 for Minutocellus polymorphus and Cylindrotheca fusiformis. A Si:N ratio of $1: 880$ was used for Phaeodactylum tricornutum. $\mathrm{N}$ : P ratios were held at $24: 1$ throughout. Cells were maintained in exponential growth for $2 \mathrm{wk}$ in the appropriate experimental medium prior to inoculation into the experimental culture vessels. Initial cell densities were 1 to $10 \%$ of the final cell yield. Samples for cell abundance, ambient silicic acid concentration, and cell-cycle stage analysis were collected daily or every other day and analyzed as described below 
Dark arrest. Since silicic acid transport is an energyconsuming process (Azam et al. 1974, Sullivan 1976), we conducted a series of experiments to determine if the pattern of cell arrest due to prolonged darkness corresponded to that under silicon starvation. The experiments were conducted using the protocol of Vaulot et al. (1986). Briefly, cells were grown in duplicate $500 \mathrm{ml}$ culture flasks containing (f/2 + Si) medium under the same light and temperature conditions as used in the silicon starvation experiments. The cultures were darkened during mid-exponential growth by wrapping each culture flask with several layers of aluminum foil. Samples for cell abundance, ambient silicic acid concentrations and cell-cycle stage analysis were taken at $30 \mathrm{~min}$ to $2 \mathrm{~h}$ intervals for $24 \mathrm{~h}$ then at 8 to $28 \mathrm{~h}$ intervals for the next $4 \mathrm{~d}$.

Silicon limitation. Chemostat cultures of Thalassiosira weissflogii, Cylindrotheca fusiformis and Chaetoceros simplex were grown using silicon-limiting (f/2+ Si) medium (see above). The chemostats were the same as used by Brzezinski \& Nelson (1988) except that all glass components were replaced with parts made of either polycarbonate, silicone or teflon. Dilution rates ranging from 0.25 to $1.11 \mathrm{~d}^{-1}$ were set by varying the volume of the chemostats and the flow rates. Chemo. stat volumes ranged from 250 to $400 \mathrm{ml}$.

The chemostats were inoculated with exponentially growing cells and allowed to come to steady state. The cultures were assumed to be in steady state when 2 criteria were met. First, sufficient time had to have elapsed such that $>99.5 \%$ of the cells which originally grew up in each chemostat would have been theoretically washed out. This criterion was adopted to ensure that essentially all cells present at the time of sampling deposited their frustules under silicon-limiting conditions. The second criterion was that the in vivo fluorescence of the culture measured every other day had to vary less than $5 \%$ for 3 samplings (i.e. 6 d). A batch culture was grown in parallel with the chemostats to provide data at the maximum growth rate. Samples for cellular silicon content, ambient silicic acid concentration, cell numbers, and cell-cycle stage analysis were collected during mid-exponential growth for the batch culture and at steady state for the chemostats.

Analytical methods. Generally, cell abundances were determined using Fuchs Rosenthal and improved Neubauer hemocytometers. In the case of the chemostat experiments with Cylindrotheca fusiformis, cell abundances and cell volumes were determined with a Coulter Multisizer ${ }^{(i)}$ particle counter. Cellular silicon, nitrogen and carbon contents were determined as described by Brzezinski (1985). Silicic acid concentrations were determined according to Strickland \& Parsons (1972) modified to use the reagent blank described by Brzezinski \& Nelson (1986). 
Samples for cell-cycle stage determination were preserved in methanol for at least $24 \mathrm{~h}$ (e.g. Olson et al. 1986a). Then an aliquot containing ca $10^{6}$ cells was suspended in $1.5 \mathrm{ml}$ of isotonic phosphate buffer $(\mathrm{pH}=$ $7,5,5 \mathrm{~g} \mathrm{l}^{-1} \mathrm{NaCl}$ ), centrifuged and resuspended in $0.5 \mathrm{mi}$ of the same buffer containing RNase (1250 units, Worthington) and propidium iodide $\left.(5 \mu \mathrm{g} \mathrm{m})^{-1}\right)$. The samples were incubated for 1 to $2 \mathrm{~h}$ at room temperature, sonicated for 1 min (Bransonic Model B-1200R-1) and the cells analyzed for their relative DNA content on an EPICS $V$ flow cytometer as described by Olson et al. (1986a). In some samples, seawater salts which had precipitated in the methanol picked up the stain and interfered with the analysis on the flow cytometer. This precipitate was dissolved by suspending a new aliquot of the methanol-preserved sample in isotonic acidic solution $\left(0.05 \mathrm{~N} \mathrm{HCl} 5.0 \mathrm{~g} \mathrm{l}^{-1} \mathrm{NaCl}\right)$ for 5 to $10 \mathrm{~min}$ whereafter the cells were resuspended in isotonic phosphate buffer and processed as described above.

The percentages of cells in $\mathrm{G} 1, \mathrm{~S}$ and $(\mathrm{G} 2+\mathrm{M})$ were calculated from the frequency histograms of relative cellular DNA content according to Vaulot et al. (1987). Since the configuration of our flow cytometer did not allow discrimination of post-mitotic cells from those in G2, the percentage of cells which had undergone karyokinesis, designated $M$, was determined by staining the methanol-preserved cells with Hoechst 33342 $\left(5 \mathrm{~kg} \mathrm{ml} \mathrm{m}^{-1}\right)$ in isotonic phosphate buffer $(\mathrm{pH}=6.8,5 \mathrm{~g}$ $1^{-1} \mathrm{NaCl}$ ). The cells were sonicated as described above and the percentage of cells with double nuclei determined by examining 500 cells using epifluorescent microscopy (excitation wavelength $=365 \mathrm{~nm}$, emission wavelength $=420 \mathrm{~mm}$ ). Thus, $M$ is operationally defined and includes cells which have undergone karyokinesis, those in the cell wall forming stage and pairs of daughter cells which have completed cell wall formation but have not yet separated. The percent of cells in G2 was then determined by difference. The durations of $G 1, S, G 2$ and $M$ in the steady-state chemostats were calculated from the doubling time of the cultures and the percent of cells in each cell-cycle stage at steady state using the equations of Slater et al. (1977).

\section{RESULTS}

\section{Exponential growth}

There was considerable interspecific variability in the percent of the generation time accupied by each stage of the cell cycle during exponential growth (Table 1). The 2 Chaetoceros species spent most of their generation time in G1 while others such as Thalassiosira pseudonana, Cylindrotheca fusiformis and Phaeo- dactylum tricornutum spent a greater fraction of their cell cycles in G2. Thalassiosira weissflogii appeared unusual in that both $\mathrm{S}$ and $\mathrm{M}$ comprised relatively large fractions of the cell cycle (Table 1).

The need for diatoms to form a new siliceous valve before cell division suggests that the percent of the cell cycle occupied by $(G 2+M)$ might be related to the degree of silicification of the frustule. This expectation was not supported by the data. There was no relationship ( $\mathrm{p}=0.05$ ) between either the absolute time spent in $(G 2+M)$ or the percent of the cell cycle occupied by these stages and the cellular silicon content. These relationships were not improved when cellular silicon was normalized to cellular carbon, cellular nitrogen or cell surface area.

\section{Silicon starvation}

When Thalassiosira weissflogii cells were starved for silicic acid high percentages of cells arrested in both G1 and G2 (Fig. 1A, B). The percent of $T$. weissflogii cells blocked in G1 was about the same as present in this stage during exponential growth, while the percentage of cells blocked in G2 was over a factor of 2 higher (Fig. 1A). The increase in the fraction of cells in G2 was paralleled by an equally strong decline in the percent of cells in S (Fig. 1A) indicating that cells were able to move through $\mathrm{S}$ as silicon availability decreased, but arrested late in the cell cycle. A significant percentage of cells were in $M$ when silicic acid was first depleted (Fig. 1A, B). The percent of cells in $\mathrm{M}$ declined slowly during the next several days (Fig. 1A). This decline may reflect the separation of daughter cells in G1 since $T$. weissflogii cells spend up to $25 \%$ of their cell cycles as postmitotic doublet cells (Vaulot 1985) which would have been included in our operationally defined $M$

Cylindrotheca fusiformis cells were mainiy present in G1 when silicon was first depleted (Fig. 1C, D) consistent with the strong silicon-dependent arrest point at the G1/S boundary in this species (Darley 1969, Darley \& Volcani 1969). As was the case for Thalassiosira weissflogii, cells in $\mathrm{S}$ were able to complete DNA synthesis despite low ambient silicic acid concentrations. The rise in the percent of cells in $\mathrm{M}$ below an ambient silicic acid concentration of about 1 uM suggests that valve formation was suppressed at these substrate concentrations (Fig. 1C). The subsequent decline in the percent of cells in both M and G1 and the corresponding rise in the percent of cells in G2 indicates that some cells completed mitosis and divided. Many more completed G1, passed through S and arrested in G2. The lack of an increase in the percentage of cells in $\mathrm{S}$ despite the movement of many cells through this stage suggests that cells spent little time in 
Fig. 1 (A, B) Thalassiosira weissflogii and (C, D) Cylindrotheca fusiformis. Time course of $(A, C)$ percent of cells in $G 1(\square), S(O), G 2(\Delta)$ and $M$ $(\nabla)$ and $(B, D)$ ambient silicic acid concentration (: $\sqsupset$ ), cell abundance $(\Delta)$ and abundance of empty frustules $(\diamond)$ during growth of batch cultures in silicon-limiting $f / 2$ medium. Error bars represent 1 standard deviation of duplicate cultures. Where no error bars are drawn

they fit inside the symbol
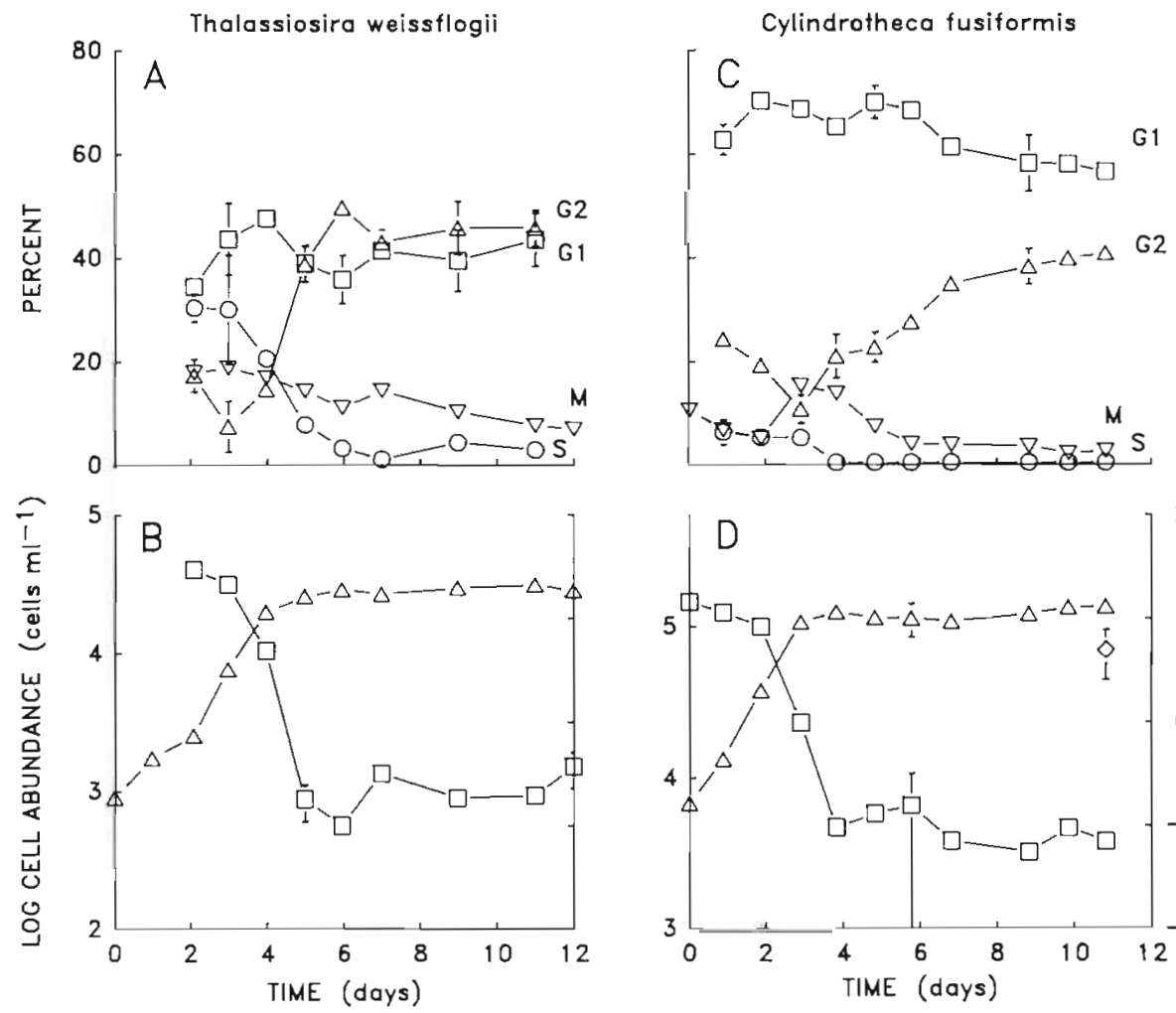

S consistent with the short duration of this stage during exponential growth (Table 1) and the insensitivity of this stage to silicon deprivation. Large numbers of empty frustules were observed on Day 11 in both cultures of C. fusiformis (Fig. 1D). Empty frustules were not observed in the $T$. weissflogii cultures.

The percent of Thalassiosira pseudonana and Minutocellus polymorphus cells arresting in G1 was high (70 to $80 \%$ ) and nearly equal to that present in G1 during exponential growth (Fig. 2). Cells of both species were able to complete DNA replication at low ambient silicic acid concentrations as observed for $T$. weissflogii and Cylindrotheca fusiformis. Residual silicic acid concentrations increased and large numbers of empty frustules appeared in cultures of both species after silicic acid depletion (Fig. 2B, D) indicating that cells were dying. Empty frustules would be expected to dissolve at significant rates at $19^{\circ} \mathrm{C}$ (Kamatani et al. 1981, Kamatani 1982) and increases in the ambient silicic acid concentrations were observed (Fig. 2B, D). The introduction of this new source of silicic acid may have released cells from silicon-starvation arrest causing the movement of cells within the cell cycle (Fig. 2A, C). Some $\mathrm{G} 2$ cells appeared to move into $\mathrm{M}$ after silicic acid depletion (Fig. 2A, B). In the case of $T$. pseudonana, some cells then divided, and cells in G1 moved through S into G2 (Fig, 2A). Alternatively, cell death could have given the appearance of cell cycling provided there was disproportionate mortality among cells in different stages of the cell cycle. The latter was an insignificant factor as the number of dead cells never exceeded $3 \%$ of the living population.

The 2 Chaetoceros species responded similarly to Thalassiosira pseudonana and Minutocellus polymorphus in that cells arrested mainly in G1 when silicic acid was depleted (Fig. 3). Then ambient silicic acid concentrations rose and large number of empty frustules were observed (Fig. 3B, D). The rise in the number of dead cells matched the decline in the number of living cells for both species indicating that little cell division was occurring. The G1 and G2 peaks in the DNA histograms broadened severely with the appearance of the dead cells making it impossible to calculate the percentage of $C$. simplex cells in each stage of the cell cycle beyond Day 4. Empty frustules were also abundant in the C. muellerii cultures following silicic acid depletion, but the number of living cells did not decline as dramatically as in the C. simplex cultures (Fig. 3D). There was a slight rise in silicic acid concentrations after Day 8 and $C$. muellerii cells appeared to move through $\mathrm{G} 1$ and $\mathrm{S}$ and accumulate in G2 and M (Fig. 3C, D). However, cell mortality was sufficient to have given the appearance of cell cycling provided that the mortality rate was not equal among stages of the cell cycle (Fig. 3D).

Microscopic examination of exponential cultures of Chaetoceros simplex and C. muellerii revealed that the daughter cells were pushed apart by the newly forming 

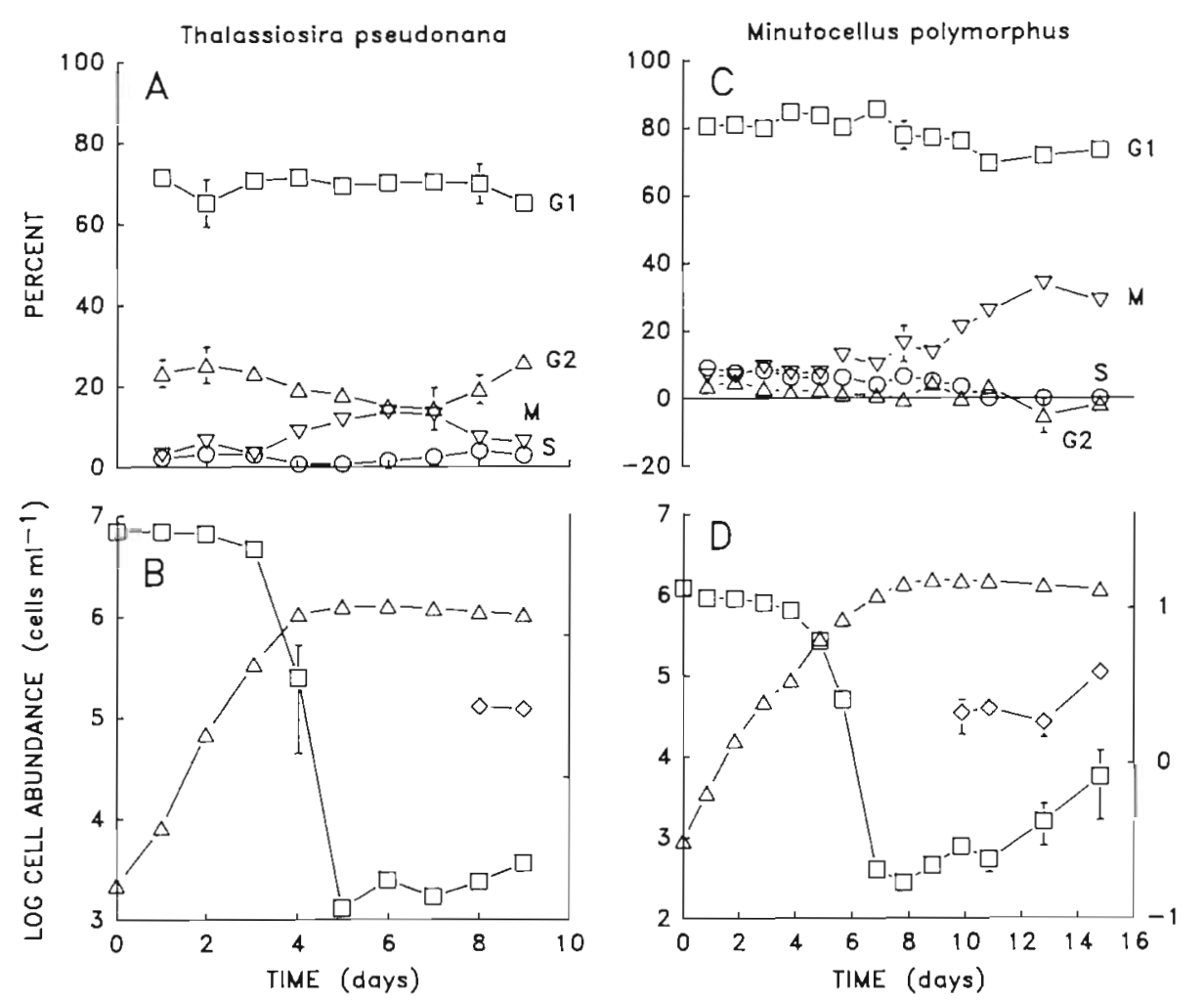
․․ Fig. 2. (A, B) Thalassiosira pseudonana and (C, D) Minutocellus polymorphus. Time course of $(A, C)$ percent of cells in G1, S, G2 and $M$, and $(B, D)$ ambient silicic acid concentration and cell abun- dance during growth of batch cultures in silicon-limiting $\mathrm{f} / 2$ medium. Symbols and error bars as in Fig. 1

setae indicating that the setae began forming at or near the beginning of $\mathrm{G} 1$. The setae contain a large fraction of the cellular silicon. Using a modification of the were cleaved from the cells by sonication (Bransonic model LS75), we determined that the setae contain 90 and $76 \%$ of cellular silicon for $C$ simplex and $C$. method of Rogerson et al. (1986) in which the setae muellerii, respectively, which are close to the value of
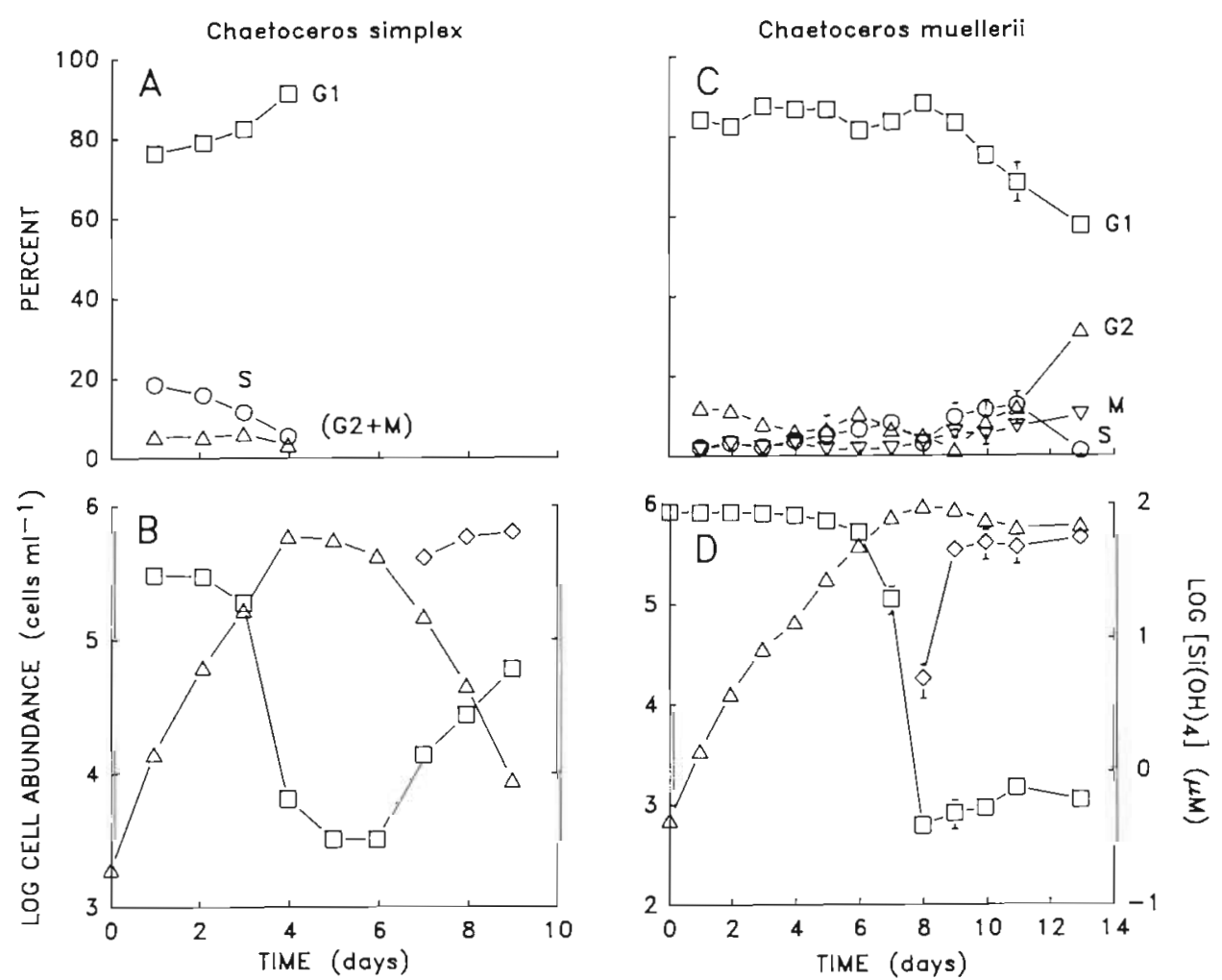

Fig. 3. (A, B) Chaetoceros simplex and (C, D) Chaetoceros muellerii. Time course of $(A, C)$ percent of cells in G1, S, G2 and $M$, and $(B, D)$ ambient silicic acid concentration and cell abundance during growth of batch cultures in siliconlimiting $t / 2$ medium. Symbols and error bars as in Fig. 1 


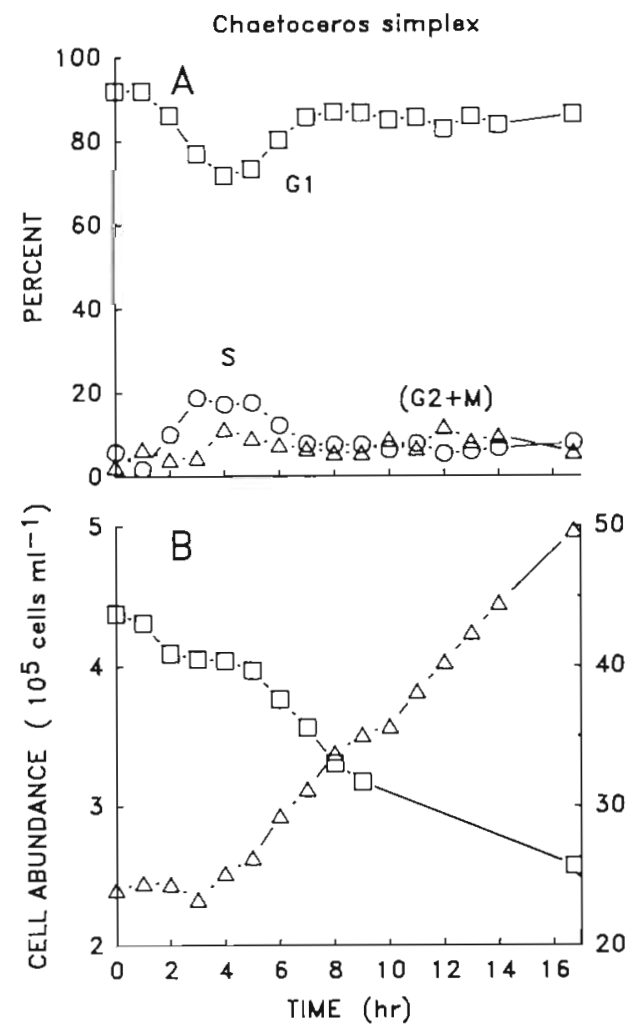

$85 \%$ measured for C. gracilis by Rogerson et al. (1986). We performed a series of experiments to determine whether the silicon-dependent arrest point in G1 in Chaetoceros actually represented 2 separate arrest points: one located at the G1/S boundary associated with the silicon requirement for DNA synthesis and another earlier in G1 associated with the deposition of siliceous setae. The presence of 2 arrest points in G1 would not have been detected by the flow cytometer since cells at all locations within G1 have the same amount of nuclear DNA.

The silicon starvation experiments with Chaetoceros simplex and $C$. muellerii were repeated and again almost all of the cells were arrested in G1 at the time of the silicic acid minimum (94\% for each). Microscopic examination of 500 arrested cells of each species showed that many cells had only one pair of setae (i.e. the pair inherited from the mother cell). The percent of cells with only one pair of setae rose from $3.8 \%$ during exponential growth to $53 \%$ at the time of silicic acid depletion for $C$. simplex. The corresponding data for $C$. muellerii are 3.3 and $28 \%$. The fact that setae begin to form just after daughter cell separation in Chaetoceros (see above) suggests that the increase in the percent of cells with only one pair of setae under silicon starvation was due to the arrest of cells early in G1

The percent of cells with a single pair of setae was considerably less than the fraction of cells arresting in G1. The location of the remaining cells was determined
Chaetoceros muellerii

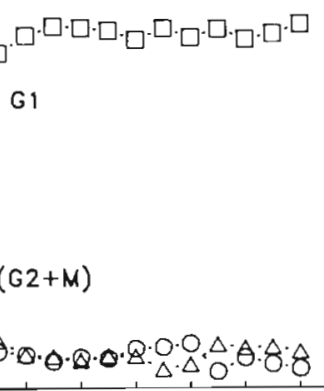

Fig. 4. (A, B) Chaetoceros simplex and (C, D) Chaetoceros muellerii. Time course of $(A, C)$ percent of cells in G1, $S$ and $(G 2+M)$, and $(B, D)$ ambient silicic acid concentration and cell abundance following the addition of fresh medium to cultures that had been starved of silicic acid. Fresh medium was added immediately prior to time 0 . Symbols as in Fig. 1 TIME (hr)

by diluting a portion of the cultures with fresh medium on the day of silicic acid depletion and monitoring cell numbers, ambient silicic acid concentrations and the movement of cells through the cell cycle for the next 16 h. A wave of cells of both species entered S shortly after the addition of fresh medium (Fig. 4) indicating that these cells were arrested close to the G1/S boundary. The percentages of cells exiting $G 1$ with these initial waves were estimated from the increase in the percent of cells in $S$ and $G 2$ following release after correcting for cell division. Thirty-four percent of the Chaetoceros simplex cells and $52 \%$ of the C. muellerii cells initially present in G1 entered S with the initial waves. The cells arrested at the G1/S boundary together with those arrested at the setae formation stage account for $90 \%$ of all C. simplex cells and $82 \%$ of all C. muellerii cells originally arrested in G1, indicating that most cells blocked in G1 were present either at the setae formation stage or near the G1/S boundary. The remaining G1 cells may have been blocked shortly after the initiation of setae deposition since cells with 2 pairs of setae, but of different length, were also observed.

A second wave of $\mathrm{S}$ cells associated with the passage of cells arrested in the setae forming stage was not observed for either species (Fig. 4A, C). These cells may have been arrested near the beginning of G1 and resumed their movement through the cell cycle at different rates or they may have arrested over a large segment of G1. In either case, large fractions of the 


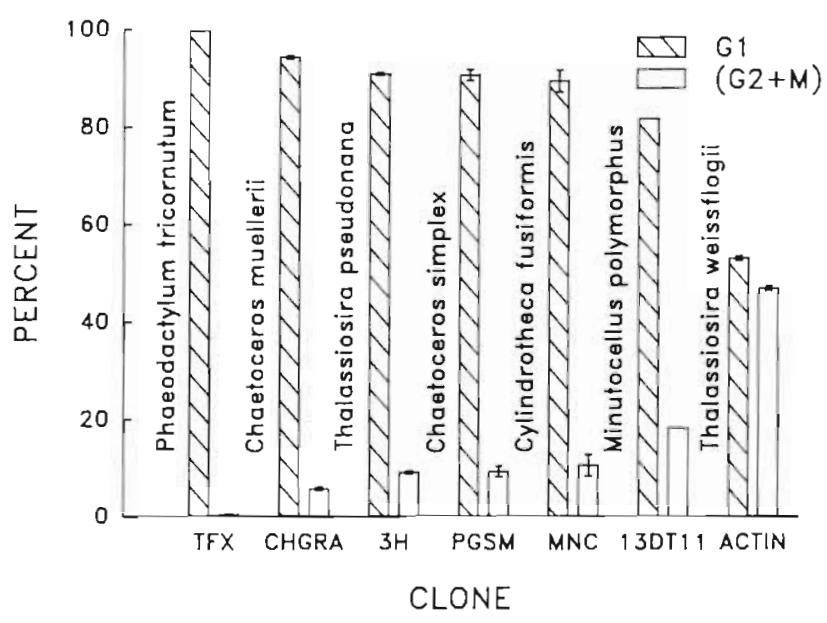

Fig. 5. Percent of cells arrested in $\mathrm{G} 1$ and $(\mathrm{G} 2+\mathrm{M})$ after cell cycle progression ceased due to prolonged darkness. Cells did not arrest in $\mathrm{S}$. Error bars represent the standard deviation of duplicate cultures

cells arresting in G1 $(66 \%$ and $48 \%$ for Chaetoceros simplex and C. muellerii, respectively) arrested before the G1/S boundary and many of these 56 and $30 \%$ for C. simplex and C. muellerii, respectively) possessed a single pair of setae.

Phaeodactylum tricornutum had a unique response to silicon starvation. The division rate of this species is not retarded by silicon deprivation (data not shown) indicating the lack of a silicon-dependent segment within its cell cycle. This observation agrees with that of D'Elia et al. (1979) who also found that the division rate of this diatom was unaffected by a lack of silicon.

\section{Dark arrest}

With the exception of Phaeodactylum tricornutum, cells placed in the dark arrested in both $\mathrm{G} 1$ and (G2+ $\mathrm{M}$ ), but not in $\mathrm{S}$ (Fig. 5). This pattern is similar to that observed under silicon starvation (Figs. 1 to 3). Cells of $P$. tricornutum arrested in G1 only (Fig 5) which is identical to the behavior of other species that lack a silicon requirement for growth (Olson \& Chisholm 1986, Olson et al. 1986a). The precent of cells of each species arresting in $\mathrm{G} 1$ and $(\mathrm{G} 2+\mathrm{M})$ in the dark was significantly correlated to the percent of cells arresting in the corresponding stages under silicon starvation $[\mathrm{r}=0.89$, $p=0.01, n=7$ for $G 1 ; r=0.78, p<0.05, n=7$ for $(G 2+$ M)] suggesting a common basis for the patterns of cell arrest in the dark and with silicon starvation.

\section{Silicon limitation}

Whereas progression through the cell cycle ceases when a silicon-starved cell reaches a stage where a

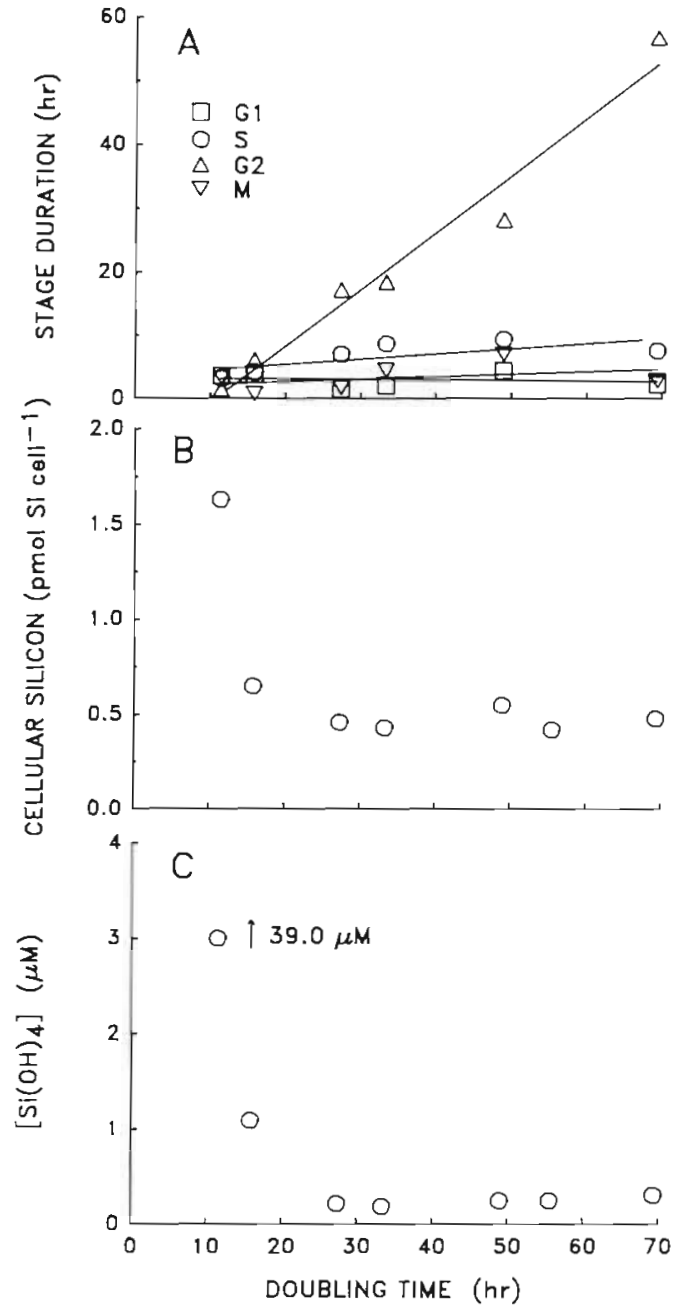

Fig. 6. Thalassiosira weissflogii. Change in (A) cell-cycle stage durations, (B) cellular silicon content, and (C) residual silicic acid concentration as a function of the average population doubling time under silicon limitation. Data at the maximal growth rate was obtained from an exponential batch culture Data at all other doubling times were obtained from steadystate chemostat cultures. Lines drawn in (A) were calculated from a linear regression of stage durations on doubling time, $t_{D}$. Only the regression line for $t_{G 2}$ on $t_{D}$ had a slope which was significantly different from zero $(p=0.05)$

need for the missing nutrient exists, a nutrient-limited cell moves through the cell cycle continually, but its rate of progression through stages of the cell cycle requiring the limiting nutrient is slowed by the low availability of that nutrient. In the case of Thalassiosira weissflogii, silicon limitation caused a dramatic increase in the duration of $\mathrm{G} 2$ with increasing silicon limitation (Fig. 6A) The durations of $S, G 1$ and $M$ remained nearly the same as observed at the maximum growth rate (Fig. 6A). For the most severely siliconlimited culture, G2 comprised over $82 \%$ of the generation time and lasted for over $2 \mathrm{~d}$ (Fig. 6A). There was a large decrease in both cellular silicon and ambient 
silicic acid concentration between the batch culture growing at the maximal rate and the silicon-limited chemostats (Fig. 6B, C). There was little difference in cellular silicon contents as a function of silicon-limited growth rate (Fig. 6B), whereas the highest dilution rate chemostat [doubling time $\left(t_{D}\right)=15.8 \mathrm{~h}$ ] did have a significantly higher residual silicic acid concentration than the others (Fig. 6C). Most of the increase in the duration of G2 occurred while both cellular silicon and residual silicic acid concentrations were low and nearly constant.

Chaetoceros simplex exhibited a more complex response to silicon limitation than Thalassiosira weissflogii (Fig. 7). Under mild silicon limitation [i.e. $t_{D}$ $<20$ h, ratio of growth rate/maximum growth rate (u) $\left.\left.\mu_{\max }\right)>0.48\right\}$, nearly the entire increase in generation time was due to the lengthening of G1 (Fig. 7A). The duration of $\mathrm{G} 2$ and $\mathrm{M}$ also increased under more severe silicon limitation (Fig. 7A). The rate of lengthening of G1 declined with increasing generation time, but G1 continued to comprise the majority of the cell cycle. Most of the increase in the duration of cell-cycle stages occurred while both cellular silicon and residual silicic acid concentrations were low and relatively constant (Fig. 7C, D).

Changes in the duration of cell-cycle stages appeared to be related to the formation of siliceous setae in G1. The percentage of cells with at least one seta was determined under phase contrast microscopy from examination of 300 to 500 cells. Of the cells in the batch culture growing at their maximum rate, $100 \%$ had 4 setae (Fig. 7B). The percentage of cells with at least one visible seta declined sharply between $t_{D}=10$ and $40 \mathrm{~h}$ coincident with the increase in the durations of $G 2$ and $M$ (Fig. 7A, B). The change in the duration of G1 was inversely correlated with the percent of cells with setae $(r=-0.94, p<0.01, n=7$; Fig. $7 \mathrm{~A}, \mathrm{~B})$.

We believe that the variable number of setae observed reflects setae breakage rather than differences in physiological state among cells. The large drop in cellular silicon between the batch culture and the chemostats suggests that the silicon content of the setae was severely reduced since the setae contain the majority of cellular silicon (see above). Thus, setae deposited under silicon limitation would be fragile compared to those produced under silicon-replete conditions making them more susceptible to breakage in the vigorously mixed cultures. Setae breakage was indeed occurring as many cells with broken or odd numbers of setae were observed in samples from the chemostats.

Modest silicon limitation of Cylindrotheca fusiformis (i.e. mean generation times $<20 \mathrm{~h}, \mu / \mu_{\max }>0.73$ ) resulted in the lengthening of $\mathrm{G} 2$ and possibly $M$, while the durations of G1 and S remained constant (Fig. 8A). Under more severe limitation, G1 also increased in duration (Fig. 8A). The lengthening of G1 occurred when the rate of decrease in cellular silicon levels and the ambient silicic acid concentrations with increasing doubling time slowed dramatically (Fig. 8C, D). There
Fig. 7 Chaetoceros simplex. Change in (A) cellcycle stage durations, (B) percent of cells with at least one seta, (C) cellular silicon content and (D) residual silicic acid concentration as a function of the average population doubling time under silicon limitation. Data at the maximal growth rate were obtained from an exponential batch culture. Data at all other doubling times were obtained from steady-state chemostat cultures. Lines drawn in (A) were calculated from polynomial regressions of cell-cycle stage durations on $t_{D}$. The regression line determined from linear regression for $t_{s}$ on $t_{D}$ had a slope which was not significantly different from zero $(\mathrm{p}=0.05)$
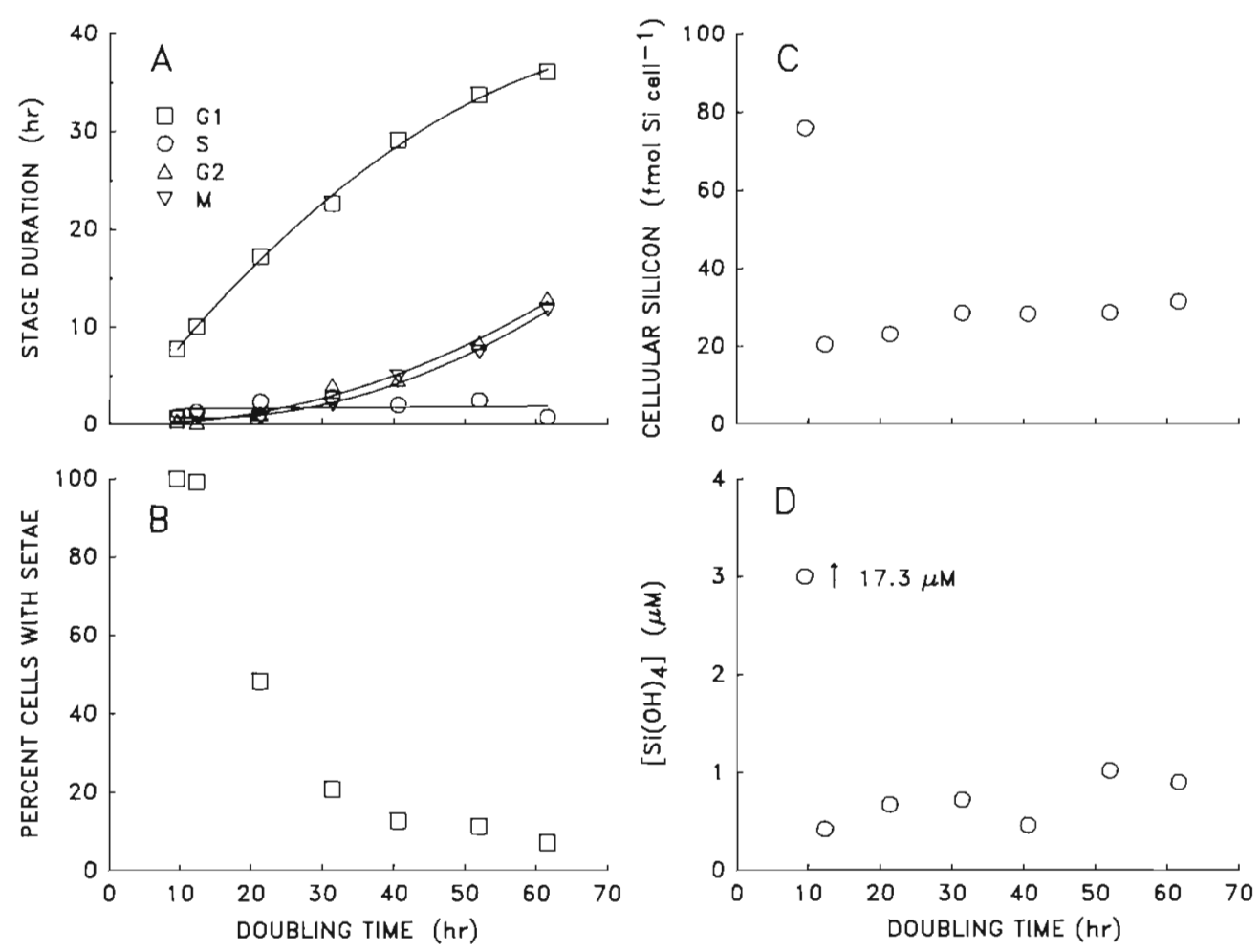

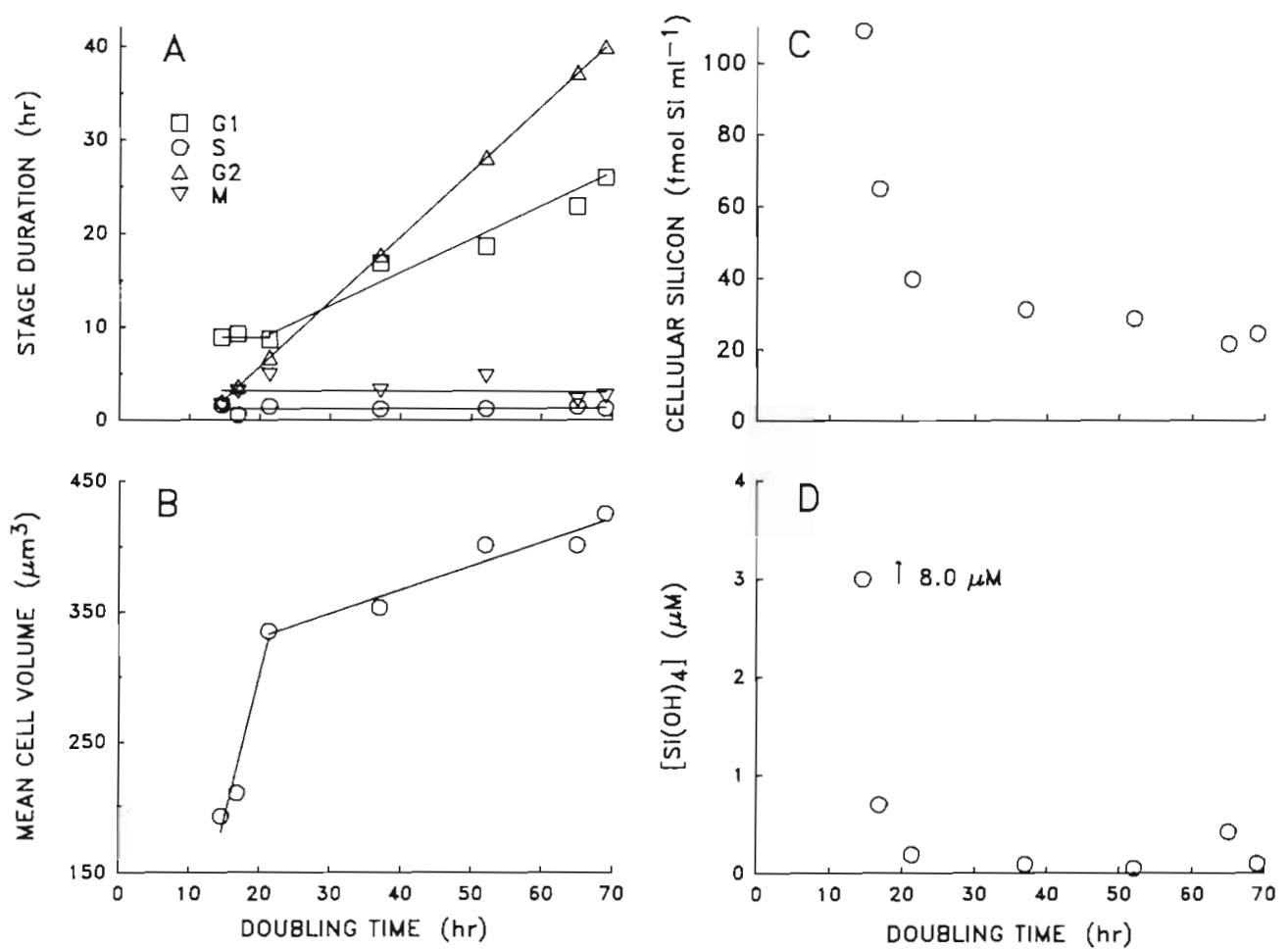

Fig. 8. Cylindrotheca fusiformis. Change in (A) cell-cycle stage durations, (B) average cell volume, (C) residual silicic acid concentration and (D) cellular silicon content as a function of the average population doubling time under silicon limitation. Data at the maximal growth rate was obtained from an exponential batch culture. Data for all other doubling times were obtained from steady-state chemostat cultures. Lines drawn in (A) were calculated from linear regressions of cell-cycle stage durations on $t_{D}$. The regression lines for $t_{M}$ beyond $t_{D}$ $=20 \mathrm{~h}$ and $\mathrm{t}_{\mathrm{s}}$ had slopes which were not significantly different from zero $(p=0.05)$

was also a sharp decline in the rate of increase in cell volume as a function of mean generation time at $t_{D}=$ $20 \mathrm{~h}$ coincident with the lengthening of G1 (Fig. 8B). The increase in cell volume with increasing doubling time (Fig. 8B) confirms past observations of large increases in cell volume in silicon-starved cultures of this species (Lewin et al. 1966). The increase in cell volume was strongly correlated with the percent of cells in (G2+M) $(\mathrm{r}=0.97, \mathrm{n}=7, \mathrm{p}<0.001)$.

\section{DISCUSSION}

\section{Exponential growth}

It was surprising that Phaeodactylum tricornutum and Cylindrotheca fusiformis spent the longest time and relatively high percentages of their cell cycles in $\mathrm{G} 2$ and $M$ (Table 1) since there are several reasons to expect these species to move relatively rapidly through the stage when valve formation occurs. Only a small portion of the valve of $C$. fusiformis is silicified (Reimann et al. 1965) and only the ovate form of $P$. tricornutum, which was not observed in our cultures, deposits a siliceous valve (Borowitzka et al. 1977 , Borowitzka \& Volcani 1978). Not surprisingly, $P$. tricornutum did not have a silicon-dependent segment in its cell cycle.

Thalassiosira weissflogii cells spent an unusually long time and large fraction of their cell cycles in $S$ and
$M$ during exponential growth (Table 1). Vaulot et al. (1987) also observed high percentages of $T$. weissflogii cells in S during exponential growth (see their Fig 2), but the reason for this remains unclear. The unusually high percentage of cells in $M$ corroborates observations by Vaulot (1985) that nutrient-replete $T$. weissflogii cells spend up to $25 \%$ of their cell cycles as post-mitotic doublet cells which would be included in our operationally defined $M$ (see 'Methods').

\section{Silicon starvation}

Interpreting the data from the silicon starvation experiments is hindered by the rise in the ambient silicic acid concentrations and the appearance of empty frustules following silicic acid depletion in many of the cultures. Silicon-starved cells can be more susceptible to bacterial attack (Kilham 1975, Tilman \& Kilham 1976) which may explain the appearance of empty frustules during stationary phase in our non-axenic cultures. Dissolution of the frustules of dead cells would resupply silicic acid to the survivors allowing the observed movement of cells within the cell cycie. Alternatively, cell death could give the appearance of cell cycling if cells from a particular stage of the cell cycle died preferentially. To avoid the problems in interpretation introduced by these potential artifacts, we confine our discussion of these results to the period from exponential growth to the time where silicic acid was first depleted 
Silicon-starved cells of Thalassiosira weissflogii and Cylindrotheca fusiformis arrested in G1 consistent with their known silicon-dependencies near the G1/S boundary associated with an apparent silicon requirement for DNA synthesis (e.g. Darley \& Volcani 1969, Vaulot et al. 1987). They also arrested in G2 and/or M, probably due to the silicon requirement for valve formation (e.g. Darley \& Volcani 1969, Vaulot et al. 1987). The 2 Chaetoceros species exhibited a unique pattern of silicon-starvation arrest in that cells arrested both at the G1/S boundary and earlier in G1. The block point at the G1/S boundary is known to exist in many diatoms (Darley 1969, Darley \& Volcani 1969, Sullivan 1976, Okita \& Volcani 1978, 1980, Blank \& Sullivan 1979. Blank et al. 1986, Vaulot et al. 1987), but the presence of a silicon-dependent block point located earlier in G1 is a new discovery. The fact that this block point involved the deposition of siliceous setae emphasizes that the number and position of silicondependent block points within the cell cycle of diatoms depends upon the timing of silicon uptake and deposition.

All species examined, with the exception of Phaeodactylum tricornutum, arrested in G2 and/or M when deprived of silicon reflecting the need for diatoms to form siliceous valves following cytokinesis. The presence of a nutrient dependency late in the cell cycle of diatoms appears unique among the eukaryotic phytoplankton and eukaryotic cells in general. Nitrogen starvation and limitation of the diatom Thalassiosira weissflogii, the coccolithophore Hymenomonas carterae and the dinoflagellate Amphidinium carteri affects G1 exclusively (Olson \& Chisholm 1986, Olson et al. 1986a, b, Vaulot et al. 1987). The presence of a silicon-dependent arrest point late in the cell cycle of the 5 centric diatoms studied here, together with similar results for several pennate species (Darley 1969, Sullivan 1976, Okita \& Volcani 1978, 1980, Blank \& Sullivan 1979, Blank et al. 1986, this study) suggests that this is a general feature of all diatoms which deposit siliceous frustules.

The silicon dependency late in the cell cycle may be related to the light-dependent segment within $\mathrm{G} 2$ in diatoms (Vaulot et al. 1986). All of the species we examined, with the exception of Phaeodactylum tricornutum, had a light-dependent segment within G2 and/ or M. This light dependency late in the cell cycle of diatoms appears to be unique among the eukaryotic phytoplankton (Chisholm 1981, Chisholm \& Brand 1981. Chisholm et al. 1984) and may be linked to the energetic requirements for silicon transport and deposition during valve formation prior to cell division (Vaulot et al. 1986). This would explain why $P$. tricornutum, which does not require silicon for growth, lacks a lightdependent segment late in its cell cycle. It would also explain why the light dependency of G2 progression in Cylindrotheca fusiformis (Fig. 5) is eliminated when the cells are grown heterotrophically in darkness (Lewin \& Hellebust 1970)

\section{Silicon limitation}

Slow progression through a stage of the cell cycle under silicon limitation could result from substrate limitation of silicon transport. A low rate of supply of silicon to the site of deposition inside the cell could lengthen the time spent constructing of the frustule. Cells could theoretically compensate for this low rate of supply by producing thinner frustules. This may be the case for Chaetoceros simplex, where the drop in setae production with increasing silicon limitation during G1 may have reduced the rate of increase in the duration of $G 1$ (Fig, 7). A similar situation occurred in Cylindrotheca fusiformis where the drop in cellular silicon under modest silicon limitation (Fig. 8C) may have delayed the expansion of $\mathrm{G} 1$ as the generation time increased (Fig. 8A)

Nutrient transport and assimilation can be coupled in at least 2 ways and yield the same pattern of cell-cycle stage expansions under nutrient limitation. Transport may occur continually with progression through the cell cycle slowing only during stages when assimilatory demands exceed internal reserves. Alternatively, the processes of transport and assimilation may be temporally coupled and confined to specific stages of the cell cycle. In the case of silicon, uptake and deposition are nearly coincident and appear confined to discrete portions of the cell cycle (Sullivan 1977), with deposition of siliceous valves beginning just after cytokinesis prior to daughter cell separation (e.g. Werner 1977, Crawford \& Schmid 1986). Thus, the lack of a change in the duration of $\mathrm{M}$ for Thalassiosira weissflogii cells under silicon limitation implies that the processes of karyokinesis, cytokinesis, valve formation and daughter-cell separation occurred at maximal rates irrespective of the degree of silicon limitation. A silicon reserve must have been present immediately before karyokinesis, possibly accumulated at very slow rates during the hours to days spent in G2 (Fig. 6A). The formation of such a large persistent internal pool of dissolved silicon would contradict past observations that internal pools of dissolved silicon are both relatively small and short-lived (Coombs \& Volcani 1968, Azam et al. 1974, Sullivan 1979, Binder \& Chisholm 1980). We speculate that silicon pool sizes may be significantly larger in cells that have acclimated to silicon-limiting conditions than in the rapidly growing or silicon-starved cells used in previous studies.

Modest silicon limitation of Chaetoceros simplex 
lengthened G1 almost exclusively suggesting that internal silicon reserves present after daughter cell separation were insufficient to drive setae formation at its maximal rate. Moreover, it implies that significant silicon uptake occurred during $G 1$ to complete the setae. The expansion of $G 2, M$ and $G 1$ under more severe limitation suggests that silicon uptake began in G2, continued through $M$ and into G1 until the completion of the setae. This scenario is consistent with past studies showing that silicon uptake occurs mainly during valve formation stage (Eppley et al. 1967. Sullivan 1977) since the setae of Chaetoceros are actually extensions of the valve and their deposition can begin prior to daughter cell separation (Li \& Volcani 1985). It differs from past observations in that much of the silicon in the setae appears to be taken up and deposited in early G1 rather than late in the cell cycle.

A major finding of our study was that severely silicon-limited cells spend the majority of their lives in stages of the cell cycle known to be associated with silicon metabolism. We believe that the lengthening of these stages reflects prolonged silicon uptake and/or deposition which can last for days in severely limited cells. This expands on past results from synchronized, silicon-replete batch cultures which showed that silicon uptake and deposition occur quickly (20 min to $2 \mathrm{~h}$ ) during a restricted portion of the cell cycle (see review by Sullivan \& Volcani 1981). Our data corroborate that silicon metabolism is linked to specific portions of the cell cycle, but indicate that these regions can lengthen dramatically in response to silicon limitation.

The response of the cell cycle of Thalassiosira weissflogii to silicon limitation differs markedly from that under nitrogen limitation. Increases in the generation time under silicon limitation were due to an expansion of G2, while nitrogen limitation lengthens G1 only (Olson et al. 1986a). Thus, depending on the identity of the limiting nutrient, an entirely different part of the cell cycle can be affected. It has been argued that in an environment where both nitrogen and silicon are in short supply a $T$. weissflogii cell could experience nitrogen limitation early in its lifetime during $G 1$ and silicon limitation later on during G2 (Vaulot et al. 1987).

In the simplest case, dual nitrogen-silicon limitation could occur if nitrogen uptake is confined to G1 and silicon uptake is confined to G2. While this may be largely true for silicon (Sullivan 1977), direct evidence of a cell-cycle dependency for nitrogen uptake in phytoplankton is lacking. Some diatoms, such as Skeletonema costatum, exhibit enhanced nitrogen uptake following bursts of cell division in cyclostat culture (Eppley et al. 1971), but it is presently unknown whether such periodic uptake reflects true cell-cycle dependent nitrogen uptake or the entrainment of uptake to the photocycle. A periodic ammonium supply can override the effect of a photocycle in entraining cell division in Thalassiosira weissflogii (Olson \& Chisholm 1983) suggesting some cell-cycle dependence for nitrogen uptake in this species. Reconciling the evidence that 2 nutrient elements can control different stages of phytoplankton cell cycles with past studies which show that phytoplankton growth rates are controlled by the one nutrient in shortest supply (e.g. Droop 1974, Rhee 1978, Rhee \& Gotham 1980) requires further investigation.

Acknowledgements. The authors thank Bonnie Woodward for performing the CHN analyses, Erik Zettler for technical assistance and Raffaella Casotti for identifying Minutocellus polymorphus. The manuscript benefitted from the comments of 3 anonymous reviewers. This work was supported in part by NSF grants OCE-8421041, OCE-8614488, OCE-8717261, OCE-8716966, OCE-8717950 by ONR N00014-83-K-0661 and $87-\mathrm{K}-0007$ and a WHOI postdoctoral fellowship awarded to $\mathrm{M}$. Brzezinski.

\section{LITERATURE CITED}

Azarn, F., Chisholm, S. W. (1976). Silicic acid uptake and incorporation by natural marine phytoplankton populations. Limnol. Oceanogr 21:427-433

Azam, F., Hemmingsen, B. B., Volcani, B. E. (1974). Role of silicon in diatom metabolism. VI. Silicic acid transport and metabolism in the heterotrophic diatom Nitzschia alba. Arch. Mikrobiol. 97: 103-114

Binder, B. J., Chisholm, S. W. (1980). Changes in the soluble silicon pool size in the marine diatom Thalassiosira weissflogii. Mar. Biol. Lett. 1: 205-212

Blank, G. S., Robinson, D. H., Sullivan, C. W. (1986). Diatom mineralization of silicic acid. VIII. Metabolic requirements and the timing of protein synthesis. J. Phycol. 22: 382-389

Blank, G. S., Sullivan, C. W (1979). Diatom mineralization of silicic acid. III. Si $(\mathrm{OH})_{4}$ binding and light dependent transport in Nitzschia angularis. Arch. Mikrobiol. 123: 157-164

Borowitzka, M. A., Chiappmo, M. L., Volcani, B. E. (1977). Ultrastructure of a chainforming diatom Phaeodactylum tricornutum. J. Phycol. 13: 162-170

Borowitzka, M. A., Volcani, B. E. (1978). The polymorphic diatom Phaeodactylum tricornutum: ultrastructure of its morphotypes. J. Phycol. 14: 10-21

Brzezinski, M. A. (1985). The Si : C:N ratio of marine diatoms: interspecific variability and the effect of some environmental variables. J. Phycol. $21 \quad 347-357$

Brzezinski, M. A., Nelson, D. M. (1986). A solvent extraction method for the colorimetric determination of nanomolar concentrations of silicic acid in seawater. Mar Chem. 19: $139-151$

Brzezinski, M. A., Nelson, D. M. (1988). Interactions between pulsed nutrient supplies and a photocycle affect phytoplankton competition for limiting nutrients in long-term culture. J. Phycol. 24: 346-356

Brzezinski, M. A. Nelson, D. M. (1989). Seasonal changes in the silicon cycle within a Gulf Stream warm-core ring. Deep-Sea Res. 36: 1009-1030

Chisholm, S. W (1981). Temporal patterns of cell division in unicellular algae. In: Platt, T. (ed.) Physiological bases of phytoplankton ecology. Can. Bull. Fish. Aquat. Sci. 210 150-181 
Chisholm, S. W., Brand, L. E. (1981). Persistence of cell division phasing in marine phytoplankton in continuous light after entrainment to light:dark cycles. J. exp. mar Biol. Ecol. 51. 107-118

Chisholm, S. W., Morel, F. M. M., Slocum, W. S. (1980). The phasing and distribution of cell division in cycles in marne diatoms. In: Falkowski, P. J. (ed.) Primary productivity in the sea. Brookhaven Symposium in Biology No. 3. Plenum Press, New York, p. 281-300

Chisholm, S. W., Vaulot, D., Olson, R. J. (1984). Cell cycle controls in phytoplankton: comparative physiology and ecology. In: Edmunds, L. N., Jr (ed.) Cell cycle clocks Marcel Dekker, New York, p. 365-394

Coombs, J., Volcani, B. E. (1968). Studies on the biochemistry and fine structure of silica shell formation in diatoms. Chemical changes in the wall of Navicula pelliculosa during its formation. Planta 82: 280-292

Crawford, R. M. Schmid, A.-M. M. (1986). Ultrastructure of silica deposition in diatoms. In: Leadbeater, B. S. C., Riding, R. (eds.) Biomineralization in lower plants and animals. The Systematics Association, Special Volume No. 30. Clarendon, Oxford, p. 291-314

D'Elia, C. F., Guillard, R. R. L., Nelson, D. M. (1979). Growth and competition of the marine diatoms Phaeodactylum tricomutum and Thalassiosira pseudonana. I. Nutrient effects. Mar. Biol. 50: 305-312

Darley, W. M. (1969). Silicon requirement for growth and macromolecular synthesis in synchronized cultures of the diatoms, Navicula pelliculosa (Breb) Hilse and Cylindrotheca fusiformis Reimann and Lewin. Ph.D. dissertation, Univ. of California, San Diego

Darley, W M., Sullivan, C. W., Volcani, B. E. (1976). Studies on the biochemistry and fine structure of silica shell formation in diatoms. Division cycle and chemical composition of Navicula pelliculosa during light-dark synchronized growth. Planta 130: 159-167

Darley, W. M., Volcani, B. E. (1969). Role of silicon in diatom metabolism. A silicon requirement for deoxyribonucleic acid synthesis in the diatom Cylindrotheca fusiformis Reimann and Lewin. Expl Cell Res. 58: 334-342

Droop. M. R. (1974). The nutrient status of algal cells in continuous culture. J. mar. biol. Ass. U.K. 54: 825-855

Eppley, R. W., Holmes, R. W., Paasche, E. (1967). Periodicity in cell division and physiological behavior of Ditylum brightwellii, a marine planktonic diatom, during growth in lightdark cycles. Arch. Mikrobiol. 56: 305-323

Eppley, R. W., Rogers, J. N., McCarthy, J. J., Sournia, A. (1971). Light-dark periodicity in nitrogen assimilation of the marine phytoplankters Skeletonema costatum and Coccolithus huxleyi in N-limited chemostat culture. J. Phycol. $7:$ 150-154

Goering, J. J., Nelson, D. M., Carter, J. A. (1973). Silicic acid uptake by natural populations of marine phytoplankton. Deep-Sea Res. 20: 777-789

Guillard, R. R. L. (1975). Culture of phytoplankton for feeding marine invertebrates. In: Smith, W. L., Chaney, M. H (eds.) Culture of marine invertebrate animals. Plenum Press, New York, p. 29-60

Guillard, R. R. L., Kilham, P., Jackson, T A. (1973). Kinetics of silicon-limited growth in the marine diatom Thalassiosira pseudonana Hasle and Heimdal (Cyclotella nana Hustedt). J. Phycol. 9: 233-237

Harrison, P. J. (1974). Continuous culture of the marine diatom Skeletonema costatum (Greve). Cleve under silicate limitation. Ph.D. dissertation, Univ. of Washington, Seattle

Kamatani, A. (1982). Dissolution rates of silica from diatoms decomposing at various temperatures. Mar. Biol. 53: 29-35
Kamatani, A., Riley, J. P., Skirrow, G. (1981). The dissolution of opaline silica of diatom tests in sea water $\mathrm{J}$. oceanogr. Soc. Japan 36: 201-208

Kilham, S. S. (1975). Kinetics of silicon-limited growth in the freshwater diatom Asterionella formosa. J. Phycol. 11. 396-399

Lewin, J. C. (1962). Silicification. In: Lewin, R. E. (ed.) Physiology and biochemistry of algae. Academic Press, New York, p. $445-455$

Lewin, J. C., Hellebust, J. A. (1970). Heterotrophic nutrition of the marine pennate diatom Cylindrotheca fusiformis. Can. J. Microbiol. 16: 1123-1129

Lewin, J. C., Reimann, B. E., Busby, W F., Volcani, B. E. (1966). Silica shell formation in synchronously dividing diatoms. In: Cammerson, 1. L., Pedilla, G. M. (eds.) Cell synchrony. Studies in biosynthetic regulation. Academic Press, New York, p. 169-188

Li, C.-W., Volcani, B. E. (1985). Studies on the biochemistry and fine structure of silica shell formation in diatoms. IX. Sequential valve formation in a centric diatom, Chaetoceros rostrum. Protoplasma 124: 30-41

Mitchison, J. M. (1971). The biology of the cell cycle. Cambridge University Press., Cambridge

Nelson, D. M., Goering, J. J., Boisseau, D. W (1981). Consumption and regeneration of silicic acid in three coastal upwelling systems. In: Richards, F. A. (ed.) Coastal upwelling. American Geophysical Union, p. 242-256

Okita, T W., Volcani, B. E. (1978). Role of silicon in diatom metabolism. IX. Differential synthesis of DNA polymerases and DNA-binding proteins during silicate starvation and recovery in Cylindrotheca fusiformis. Biochim. Biophys. Acta 519: 76-86

Okita, T W., Volcani, B. E (1980). Role of silicon in diatom metabolism. X. Polypeptide labelling patterns during the cell cycle, silicate-starvation and recovery in Cylindrotheca fusiformis. Expl Cell Res. 125: 471-481

Olson, R. J., Chisholm, S. W (1983). Effects of photocycles and periodic ammonium supply on three marine phytoplankton species. I. Cell division patterns. J. Phycol. 19: $522-528$

Olson, R. J., Chisholm, S. W (1986). Effects of light and nitrogen limitation on the cell cycle of the dinoflagellate Amphidinium carteri. J. Plankton Res. 8: 785-793

Olson, R. J., Vaulot, D., Chisholm, S. W. (1986a). Effects of environmental stress on the cell cycle of two marine phytoplankton species. Plant Physiol. 80: 918--925

Olson, R. J., Watras, C. W., Chisholm, S. W (1986b). Patterns of individual cell growth in marine centric diatoms. J. gen. Microbiol. 132: 1197-1204

Paasche, E. (1973). Silicon and the ecology of marine plankton diatoms. I. Thalassiosira pseudonana (Cyclotella nana) grown in a chemostat with silicate as the limiting nutrient. Mar. Biol. 19: 117-126

Reimann, B. E. F., Lewin, J. C., Volcani, B. E. (1965). Studies on the biochemistry and fine structure of silica shell formation in diatoms. I. The structure of the cell wall of Cylindrotheca fusiformis Reimann and Lewin. J. Cell Biol. 34: $39-55$

Rhee, G.-Y. (1978). Effects of N:P atomic ratios and nitrate limitation on algal growth, cell composition and nitrate uptake. Limnol. Oceanogr. 23: 10-25

Rhee, G.-Y., Gotham, I. J. (1980). Optimum N:P ratios and coexistence of planktonic algae. J. Phycol. 16: 486-489

Rogerson, A., DeFreitas, S. W., McInnes, A. G. (1986). Growth rates and ultrastructure of siliceous setae of Chaetoceros gracilis (Bacillariophyceae). J. Phycol. 22: 56-62

Slater, M. L. Sharrow, S. O., Gart, J. J. (1977). Cell cycle of 
Saccharomoyces cerevisiae in populations growing at different rates. Proc. natn. Acad. Sci. U.S.A. 74: 3850-3854

Strickland, J. D. H., Parsons, T. R. (1972). A practical handbook of seawater analysis, 2nd edn. Fish. Res. Bd Can. Bull. 167

Sullivan, C. W. (1976). Diatom mineralization of silicic acid. I. $\mathrm{Si}(\mathrm{OH})_{4}$ transport characteristics in Navicula pelliculosa. $\mathrm{J}$. Phycol. 12: 390-396

Sullivan, C. W. (1977). Diatom mineralization of silicic acid. II. Regulation of $\mathrm{Si}(\mathrm{OH})_{4}$ transport rates during the cell cycle of Navicula pelliculosa. J. Phycol. 13: 86--91

Sullivan, C. W (1979). Diatom mineralization of silicic acid. IV Kinetics of soluble Si pool formation in exponentially growing and synchronized Navicula pelliculosa. J. Phycol. 15: $210-216$

Sullivan, C. W. Volcani, B. E. (1981). Silicon in the cellular metabolism of diatoms. In: Simpson, T L., Volcani, B. E. (eds.) Silicon and siliceous structures in biological systems. Springer-Verlag, Heidelberg, p. 15-41

Thomas, W. H., Dodson, A. N. (1975). On silicic acid limitation

This article was submitted to the editor of diatoms in nearsurface waters of the eastern tropical Pacific Ocean. Deep Sea Res. 22: 671-677

Tilman, D., Kilham, S. S. (1976). Phosphate and silicate growth and uptake kinetics of the diatoms Asterionella formosa and Cyclotella meneghiniana in batch and semicontinuous culture. J. Phycol. 12: 375-383

Vaulot, D. (1985). Cell cycle controls in marine phytoplankton. Ph.D. thesis, Massachusetts Institute of Technology/Woods Hole Oceanographic Institution (Ref. WHOI-85-10)

Vaulot, D., Olson, R. J., Chisholm, S. W. (1986). Light and dark control of the cell cycle in two marine phytoplankton species. Expl Cell Res. 167: 38-52

Vaulot, D., Olson, R. J., Merke, S., Chisholm, S. W. (1987). Cell-cycle response to nutrient starvation in tow phytoplankton species, Thalassiosira weissflogii and Hymenomonas carterae. Mar. Biol. 95: 625-630

Werner, D. (1977). Silicate metabolism. In: Werner, D. (ed.) The biology of diatoms. Bot. Mon., Univ. Calif. Press., Berkeley, p. 110-149

Manuscript first received: February 16, 1990

Revised version accepted: July 6, 1990 